\title{
ENERGY DEMAND IN CITRUS PRODUCTION UNDER VARIED OPERATIONAL EFFICIENCY VALUES
}

\section{NELSON C. FRANCO JUNIOR ${ }^{1}$, MARCOS MILAN ${ }^{2}$, THIAGO L. ROMANELLI ${ }^{3}$}

\begin{abstract}
Citrus orchards are very important in Brazil, especially in São Paulo State, where occupy an area of 600,000 ha approximately. To identify sustainability degree of citrus production system, an energy analysis allows evaluating efficiency of direct and indirect applied inputs. Thus, this study aimed to evaluate citrus production system under energetic point of view, in which invested energy is paid back with citrus production; being compared within three scenarios for operational field efficiency. As result, by sensitivity analysis was determined that fuel was the main energy demander, followed by pesticides and fertilizers. In operational work capacity analysis, all combinations between efficiency (minimum, typical and maximum) and yield levels became positive in the seventh year, except for the combination minimum efficiency and $10 \%$ less yield, positive in the eighth year. The best combination (maximum efficiency and $10 \%$ more yield) has promoted investment payoff around the sixth and seventh year. By this study, it is possible to determine the total energy demand to produce citrus and indentify the applied inputs that need more attention by the decision-makers. Labor and seedlings can be ommited for further studies with citrus, since they were irrelevant. Management of agricultural machinery may pose an important role on decreasing environmental impact of citrus production.
\end{abstract}

KEYWORDS: energy balance, EROI, machinery management, sustainability.

\section{DEMANDA DE ENERGIA NA PRODUÇÃO DE CITROS COM DIFERENTES EFICIÊNCIAS OPERACIONAIS}

RESUMO: A atividade citrícola apresenta grande importância no Brasil, especialmente no Estado de São Paulo, onde são plantados 600 mil ha, aproximadamente. Para identificar o nível de sustentabilidade do sistema de produção, a análise energética permite avaliar a eficiência na utilização dos insumos direta ou indiretamente aplicados (estes determinados pela capacidade operacional). Assim, este estudo teve como objetivo avaliar o sistema produtivo de laranja do ponto de vista energético, em que a energia investida é paga pela produção de frutos, sendo comparada nos três cenários para a eficiência operacional de campo. Pela análise de sensibilidade, determinou-se que o combustível foi o principal demandante de energia, seguido pelos fitossanitários e fertilizantes. Na análise da capacidade operacional, todas as combinações entre eficiência (mínima, típica e máxima) e nível de produtividade tornaram-se positivas no sétimo ano, exceto mínima eficiência e -10\% produtividade, positiva no oitavo ano. A melhor combinação (máxima eficiência e $+10 \%$ produtividade) recupera seu investimento no limite entre o sexto e o sétimo anos. Pelo estudo, foi possível determinar o total de energia demandada para a produção de laranjas e identificar os insumos aplicados que merecem maior atenção dos tomadores de decisão. Mão de obra e mudas podem ser desconsideradas em trabalhos futuros, uma vez que foram irrelevantes.

PALAVRAS-CHAVE: balanço energético, EROI, gerenciamento agrícola, sustentabilidade.

\footnotetext{
${ }^{1}$ Eng $^{\circ}$ Agrônomo, Doutorando, Laboratório de Gestão Sistêmica e Sustentabilidade/PPG em Engenharia de Sistemas Agrícolas, USP-ESALQ/Piracicaba - SP, Fone: (19) 3447-8510, ncfranco@usp.br.

${ }^{2}$ Eng $^{\circ}$ Agrônomo, Prof. Associado III, Laboratório de Gestão Sistêmica e Sustentabilidade/Departamento de Engenharia de Biossistemas, USP-ESALQ/Piracicaba - SP, Fone: (19) 3447-8501, macmilan@usp.br.

${ }^{3}$ Eng $^{\circ}$ Agrônomo, Prof. Associado I, Laboratório de Gestão Sistêmica e Sustentabilidade/Departamento de Engenharia de Biossistemas, USP-ESALQ/Piracicaba - SP, Fone: (19) 3447-8523, romanelli@usp.br.
} 


\section{INTRODUCTION}

Citrus stands for more than $20 \%$ of worldwide fruit production with about 120 million tons (FAO, 2011). Brazil is the largest producer with 18 million tons and 840 thousand hectares, besides being the world greatest juice exporter. São Paulo State is responsible for $80 \%$ of Brazilian production, followed by Bahia and Sergipe States (AGRIFNP, 2011). Between 1999 and 2009, citrus profitability has decreased because of the increase in land price $(+130 \%)$ and production cost (+32\%) plus the price fall (-20\%), although yield has increased 25\% (BOTEON \& PAGLIUCA, 2010). Production cost increased due to pest and disease control as greening emerged (HLB), which is caused by Candidatus liberibacter bacteria, being transmitted by Diaphorina citri (GRAFTONCARDWELL et al, 2013). Current global market and increasing competitiveness makes corporations become more efficient in resource use and waste reduction to improve sustainability towards growth. Additionally, there is a growing environmental awareness (JACOVINE et al, 2009), besides pressure by regulatory institutions and non-governmental organization (NGOs).

Energy analysis is an adequate tool to evaluate agriculture level of development as well as sustainability degree (PIMENTEL, 1980; ROMANELLI \& MILAN, 2010a), and also it has been widely used to assess efficiency of agricultural production systems (BOJACA \& SCHREVENS, 2010), despite it has been little used by this sector as a decision-making tool (ROMANELLI \& MILAN, 2010a).

To conduct this evaluation, it is required to determine material flows, which represent direct inputs (fertilizers, pesticides etc.) and indirect ones (machinery, labor, fuel) within crop production system. For direct inputs, mechanized operation efficiency plays a vital role in material intensity (ROMANELLI \& MILAN, 2010b). Energy analysis is also used to identify benefits that new techniques may infer into agricultural system management. ROMANELLI et al. (2012) used this analysis and material incorporation to compare distinct production scenarios, including a comparison of conventional and genetically modified organism (GMO) crops of soybeans in Brazil. The authors observed GMO demanded less indirect applied inputs.

JASPER et al. (2010) characterized energy consumption for deployment and conduction of Crambe abyssinica Hochst grown under no-tillage system, which was considered direct (biological and fossil), and indirect (industrial), for all inputs used in the stages: desiccation, sowing and harvest. To quantify demanded energy for the system, they applied energy coefficients related to categories such as "labor" and "inputs", which was divided into "fertilizers", "fungicides and herbicides", "machinery and equipment”, "fuel and lubricants” and “crambe seed”.

The current study aimed to establish energy flows for citrus production and monitoring how system efficiency affects energy indicators within the required mechanized operations.

\section{MATERIAL AND METHODS}

We used a method presented by ROMANELLI \& MILAN (2010b), wherein material flows of used indirect inputs were determined such as: machinery depreciation (MD), fuel consumption (Cons) and labor (LB). Subsequently, we applied these data into Equation 1; to determine demanded indirect energy ( $\left.\mathrm{IE}_{\text {ind }}\right)$, for that, machines and implements that perfomed operations were surveyed for sort data like power $(\mathrm{kW})$, mass $(\mathrm{kg})$, usefull life $(\mathrm{h})$, speed $\left(\mathrm{km} \mathrm{h}^{-1}\right)$, work width $(\mathrm{m})$ determination. Afterwards, field capacity of each tractor-implement set was determined. Field capacity, machinery depreciation, labor and fuel consumption were determined as suggested by ROMANELLI \& MILAN (2010b). Fuel consmption considered specific consumption for diesel engines (0.163 $\left.\mathrm{L} \mathrm{kW}^{-1} \mathrm{~h}^{-1}\right)$ from MOLIN \& MILAN (2002).

$$
\mathrm{IE}_{\text {ind }}=\left(\mathrm{MD} * \mathrm{EC}_{\mathrm{MD}}\right)+\left(\text { Cons } * \mathrm{EC}_{\mathrm{FU}}\right)+\left(\mathrm{LB} * \mathrm{EC}_{\mathrm{LB}}\right)
$$

where,

$\mathrm{IE}_{\text {ind }}$ - indirect input energy required for citrus production $\left(\mathrm{MJ} \mathrm{ha}^{-1}\right)$;

$\mathrm{MD}$ - machinery depreciation $\left(\mathrm{kg} \mathrm{ha}^{-1}\right)$; 


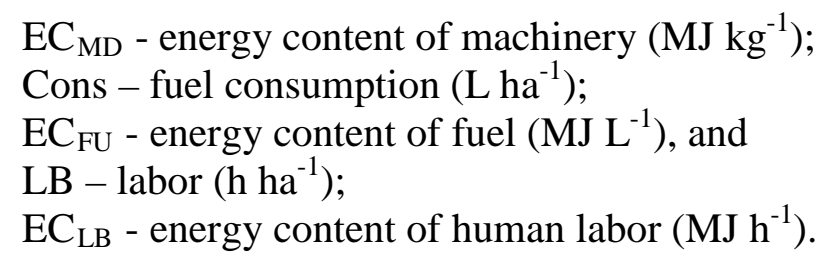

With regards to direct inputs, we collected data from agronomical prescriptions for citrus production of São Paulo State (AGRIFNP, 2011). These inputs were grouped into fertilizers, pesticides and seedling. Demanded energy by each input is the product of applied quantity and its energy content (Equation 2). where,$$
\mathrm{IE}_{\mathrm{dir}}=\text { Qty } * \mathrm{EC}
$$

$\mathrm{IE}_{\mathrm{dir}}$ - direct input energy required for citrus production $\left(\mathrm{MJ} \mathrm{ha}^{-1}\right)$;

Qty - quantity of each input applied (volume, mass or unit), and

EC - energy content of direct applied input (MJ per volume, mass or unit).

Total input energy (IE) is the sum of both indirect ( $\left.\mathrm{IE}_{\mathrm{ind}}\right)$ and direct required inputs (IE $\mathrm{dir}_{\mathrm{di}}$ ). Output energy (OE) stands for the energy provided by fruit production. Thus, it is determined considering citrus yield and its energy content (Equation 3).

where,

$$
\mathrm{OE}=\mathrm{CY}^{*} \mathrm{EC}_{\mathrm{fr}}
$$

OE - Output energy $\left(\mathrm{MJ} \mathrm{ha}^{-1}\right)$;

CY - citrus yield $\left(\mathrm{kg} \mathrm{ha}^{-1}\right)$, and

$\mathrm{EC}_{\mathrm{fr}}$ - fruit energy content (1.90 $\mathrm{MJ} \mathrm{kg}^{-1}$; PIMENTEL, 2009).

In this study, it was considered energy balance as net energy of a production system (Eq. 4), energy return on investment (EROI), which is the ratio of obtained energy from an energy production process and required energy (or its equivalent from some other source) in a production system (MURPHY \& HALL, 2010), represented by Equation 5. Another evaluated indicator is embodied energy (EE), which represents the amount of energy incorporated per produced mass (Eq. 6). The latter was determined either for fruit mass or vitamin $C$ content, which allow further comparisons with other production systems that provide vitamin sources.

$$
\begin{aligned}
& \mathrm{EB}=\mathrm{OE}-\mathrm{IE} \\
& \mathrm{EROI}=\mathrm{OE} / \mathrm{IE} \\
& \mathrm{EE}=\mathrm{IE} / \mathrm{CY}
\end{aligned}
$$

where,

EB - energy balance $\left(\mathrm{MJ} \mathrm{ha}^{-1}\right)$;

$\mathrm{IE}$ - sum of both indirect - $\mathrm{IE}_{\text {ind }}$ and direct required inputs - $\mathrm{IE}_{\mathrm{dir}}\left(\mathrm{MJ} \mathrm{ha}^{-1}\right)$;

EE - embodied energy $\left(\mathrm{MJ} \mathrm{kg}^{-1}\right)$.

To determine vitamin $\mathrm{C}$ production (ascorbic acid production), we assumed an average content of $0.625 \mathrm{~g} \mathrm{~kg}^{-1}$ of juice (COUTO \& CANNIATTI-BRAZACA, 2010) and a ratio juice 59 $\%$ (590g juice $\mathrm{kg}^{-1}$ fruit; CARVALHO, 2010), and multiplied the embodied energy for citrus production as an efficiency factor. Through energy analysis, the impact of changing field efficiency of mechanized operations can be evaluated for total and indirect energy demand (ROMANELLI \& MILAN, 2010b). Minimum and maximum values for efficiency were adopted from ASABE (2011). Efficiency variable affects three indirect applied inputs: labor, fuel and machinery depreciation. To obtain material flows for minimum and maximum efficiency values (Table 1), which replaced by those in Equations 2 to 4. 
TABLE 1. Mechanized operation efficiency (ASABE, 2011).

\begin{tabular}{lccc}
\hline Operations & Minimum & Field Efficiency (\%) & Typical \\
\hline Fertilizer application & 60 & 70 & Maximum \\
Furrowing & 70 & 75 & 80 \\
Harrowing & 70 & 80 & 90 \\
Harrowing (weed control) & 70 & 80 & 90 \\
Herbicide spraying & 50 & 65 & 75 \\
Insecticide spraying & 50 & 65 & 85 \\
Limestone application & 60 & 70 & 80 \\
Mowing & 70 & 80 & 90 \\
Spraying (atomizer) & 70 & 80 & 90 \\
Spraying (pistol) & 50 & 65 & 80 \\
Terracing & 70 & 80 & 85 \\
Track maintenance & 60 & 70 & 85 \\
\hline
\end{tabular}

\section{RESULTS AND DISCUSSION}

Mechanized operation that most demand indirect inputs is spraying, since it is performed around 47 times during production cycle (18 years). It requires the largest amount of machine ( $338.48 \mathrm{~kg} \mathrm{ha}^{-1}$ ), fuel (3343.05 $\mathrm{L} \mathrm{ha}^{-1}$ ) and labor (371.45 h ha-1), corresponding to $60.8 \%, 48.6 \%$ and $48,7 \%$ of total individual material flow, respectively. Fuel is responsible for $86.91 \%$ of the total indirect energy demanded (Table 2). On the other hand, labor may not be considered in further evaluations due to its little contribution $(0.55 \%)$ by energy point of view.

TABLE 2. Material and input energy flows for indirect applied inputs.

\begin{tabular}{|c|c|c|c|c|}
\hline Mechanized operations & Machine depreciation kg ha-1 & Fuel & $\mathrm{L} \mathrm{ha}^{-1}$ Labor & $\mathrm{h} \mathrm{ha}^{-1}$ \\
\hline \multicolumn{5}{|l|}{ Soil tillage } \\
\hline Limestone application & 10.67 & 90.45 & 10.05 & \\
\hline Track maintenance & 0.24 & 5.04 & 0.40 & \\
\hline Terracing & 0.67 & 6.30 & 0.70 & \\
\hline Leveling harrowing & 0.98 & 12.60 & 1.40 & \\
\hline Heavy harrowing & 2.69 & 27.90 & 3.10 & \\
\hline Subtotal & 15.24 & 142.29 & 15.65 & \\
\hline \multicolumn{5}{|l|}{ Planting } \\
\hline Fertilizer application & 1.30 & 13.95 & 1.55 & \\
\hline Seedling distribution & 0.84 & 13.50 & 1.50 & \\
\hline Wind shield & 1.68 & 27.00 & 3.00 & \\
\hline Seedling irrigation & 7.88 & 144.00 & 16.00 & \\
\hline Replanting & 0.34 & 5.40 & 0.60 & \\
\hline Furrowing & 2.56 & 54.00 & 6.00 & \\
\hline Subtotal & 14.60 & 257.85 & 28.65 & \\
\hline \multicolumn{5}{|l|}{ Conduction } \\
\hline Fertilizer application & 44.23 & 410.40 & 45.60 & \\
\hline Herbicide application & 12.17 & 333.00 & 37.00 & \\
\hline Fly control & 29.16 & 648.00 & 72.00 & \\
\hline Harrowing (weed control) & 2.10 & 27.00 & 3.00 & \\
\hline Track maintenance & 4.63 & 97.20 & 10.80 & \\
\hline Spraying & 338.48 & 3343.05 & 371.45 & \\
\hline Mowing & 55.33 & 972.00 & 108.00 & \\
\hline Subtotal & 486.11 & 5830.65 & 647.85 & \\
\hline Harvesting & 40.62 & 652.50 & 72.50 & \\
\hline TOTAL & 556.58 & 6883.29 & 764.65 & \\
\hline Energy content (MJ unit ${ }^{-1}$ ) & 68.9 & 38.6 & 2.2 & \\
\hline Unit & $\mathrm{kg}$ & $\mathrm{L}$ & $\mathrm{h}$ & \\
\hline Reference & $¥$ & $*$ & $*$ & \\
\hline Input energy (GJ ha ${ }^{-1}$ ) & 38.35 & 265.69 & 1.68 & \\
\hline Input energy (\%) & 12.54 & 86.91 & 0.55 & \\
\hline
\end{tabular}

"FERRARO JR. (1999); ${ }^{*}$ ULBANERE \& FERREIRA (1989). 
For direct inputs, pesticide (55.66\%) and fertilizer (44.23\%) were responsible for almost all demanded energy. Seedling may be unconsidered in further evaluations due to its minute energy demand (0.1\%). Pesticides presented less material flow but since they are more energy-intense, they have larger participation than fertilizer (Table 3). Insecticides and simple superphosphate sum had $49.01 \%$ of direct energy input, representing focus point for decision-makers dealing with citrus production energy approach.

TABLE 3. Material flow and energy flows of direct applied inputs.

\begin{tabular}{|c|c|c|c|c|c|c|}
\hline & \multirow[t]{2}{*}{ Unit } & \multirow{2}{*}{$\begin{array}{l}\text { Material flow } \\
\text { Qty ha }^{-1}\end{array}$} & \multirow{2}{*}{$\begin{array}{l}\text { Embodied energy } \\
\text { MJ unit }^{-1}\end{array}$} & \multicolumn{2}{|c|}{ Input energy } & \multirow[t]{2}{*}{ Reference } \\
\hline & & & & MJ ha $^{-1}$ & $\%$ & \\
\hline \multicolumn{7}{|l|}{ Fertilizer } \\
\hline S. S. phosphate & $\mathrm{kg}$ & 5510.0 & 9.8 & 53942.90 & 14.21 & $*$ \\
\hline Limestone & $\mathrm{kg}$ & 20350.0 & 1.7 & 33984.50 & 8.95 & $*$ \\
\hline$(\mathrm{NH} 4)_{2} \mathrm{SO}_{4}$ & $\mathrm{~kg}$ & 14780.0 & 22.0 & 32368.20 & 8.53 & $*$ \\
\hline Urea & $\mathrm{kg}$ & 310.0 & 78.0 & 24192.40 & 6.37 & $*$ \\
\hline $\mathrm{KCl}$ & $\mathrm{kg}$ & 3160.0 & 7.2 & 22720.40 & 5.99 & $*$ \\
\hline Micro & $\mathrm{kg}$ & 204.0 & 3.3 & 673.20 & 0.18 & $*$ \\
\hline Subtotal & & & & 167881.60 & 44.23 & \\
\hline \multicolumn{7}{|l|}{ 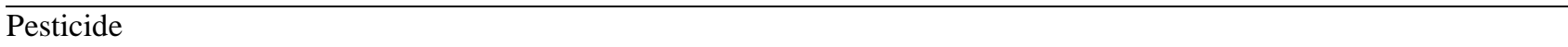 } \\
\hline Insecticide & $\mathrm{L}$ & 715.8 & 184.7 & 132209.88 & 34.84 & $£$ \\
\hline Mineral oil & $\mathrm{L}$ & 511.8 & 38.6 & 19755.87 & 5.20 & $¥$ \\
\hline Acaricide & $\mathrm{L}$ & 103.3 & 184.7 & 19082.39 & 5.03 & $£$ \\
\hline Fungicide & $\mathrm{kg}$ & 195.4 & 97.1 & 18975.32 & 5.00 & $£$ \\
\hline Herbicide & $\mathrm{L}$ & 54.3 & 254.6 & 13828.24 & 3.64 & $\underline{\varepsilon}$ \\
\hline Fly trap & $\mathrm{L}$ & 48.0 & 97.1 & 4662.24 & 1.23 & $£$ \\
\hline Sticker & $\mathrm{kg}$ & 41.2 & 38.6 & 1589.93 & 0.42 & $¥$ \\
\hline Formicide & $\mathrm{kg}$ & 12.0 & 97.1 & 1165.56 & 0.31 & $£$ \\
\hline Subtotal & & & & 211269.43 & 55.67 & \\
\hline \multicolumn{7}{|l|}{ Seedling } \\
\hline Citrus & Unit & 408.0 & 0.8 & 326.40 & 0.09 & $\S$ \\
\hline Grevillea SP & Unit & 30.0 & 0.8 & 24.00 & 0.01 & $\S$ \\
\hline Subtotal & & & & 350.40 & 0.10 & \\
\hline TOTAL & & & & 379501.43 & 100.00 & \\
\hline
\end{tabular}

Few studies have been made to update energy embodiment indexes of agricultural inputs, such as MANTOAM et al. (2014), who determined energy embodied for sugarcane harvester. Most of available data are from the 1970s and 1980s when the search for alternative energy sources due to oil shocks stimulated researchers to develop these indices.

Inseticide is responsible for the largest energy demand, with an applied volume of $715.8 \mathrm{~L}$ throughout citrus life-cycle, which result in $132 \mathrm{GJ} \mathrm{ha}^{-1}$. Fuel, pesticides and fertilizers are the main energy demanding inputs summing together $94.1 \%$ of total demanded energy (Table 4). For further studies regarding energy evaluation of perennial crops presenting similar production systems, these should be the evaluated inputs. For citrus, calcium in limestone is considered as plant fertilizer.

TABLE 4. Total demanded energy for citrus production.

\begin{tabular}{lcc}
\hline Input & $\mathrm{GJha}^{-1}$ & Energy flow \\
\hline Indirect energy & 305.73 & $\%$ \\
Fuel & 265.69 & 44.62 \\
Machine Depreciation & 38.35 & 38.77 \\
Labor & 1.68 & 5.60 \\
Direct energy & 379.50 & 0.25 \\
Pesticides & 211.27 & 55.38 \\
Fertilizers & 167.88 & 30.83 \\
Seedlings & 0.35 & 24.50 \\
TOTAL & 685.23 & 0.05 \\
\hline
\end{tabular}


Output energy determination considered 15-year of productive cycle (612.6 $\mathrm{Mg} \mathrm{ha}^{-1}$ or 15014 boxes $h^{-1}$ ) within 18-year life cycle. Average yield is 2.04 boxes per tree yearly. Indicators were determined from input and output energy flows (Table 5). There is some net energy in citrus production (EB positive) that returns back on energy inserted (EROI), whic is is higher than 1, allowing to assume that the system is sustainable. In spite of sustainable, EROI is low, however, we should highlight that citrus is not an energy crop, but a vitamin and fiber source. Thus, citrus production can be compared with other sources with same purpose.

TABLE 5. Energy indicators for the evaluated production system.

\begin{tabular}{lcc}
\hline Indicator & Value & Unit \\
\hline CY & 612587.52 & $\mathrm{~kg} \mathrm{ha}^{-1}$ \\
VcY & 225.89 & $\mathrm{~kg} \mathrm{ha}^{-1}$ \\
OE & 1163,92 & $\mathrm{GJ} \mathrm{ha}^{-1}$ \\
IE & 685.23 & $\mathrm{GJ} \mathrm{ha}^{-1}$ \\
EB yr & & $\mathrm{GJ} \mathrm{ha}^{-1} \mathrm{yr}^{-1}$ \\
EB & 26.59 & $\mathrm{GJ} \mathrm{ha}^{-1}$ \\
EROI & 478.69 & - \\
EE (citrus) & 1.70 & $\mathrm{MJ} \mathrm{kg}^{-1}$ \\
EE (vitamin C) & 1.12 & $\mathrm{MJ} \mathrm{kg}^{-1}$ \\
\hline
\end{tabular}

CY - Citrus yield; VcY - Vitamin C yield; OE - Output energy; IE - Input energy; EB - Energy balance; EROI - Energy return on investment; EE - Embodied energy.

OZKAN et al. (2004) surveyed 105 citrus farms located in Antalya province (Turkey) and verified that annual EB was $15.05 \mathrm{GJ} \mathrm{ha}^{-1} \mathrm{yr}^{-1}$ and EROI was 1.25. These production systems are irrigated, and then electricity and water consumption were also accounted in input energy.

PIMENTEL (2009) evaluated 12 citrus orchard production in developed and developing countries. The authors obtained the amount of $83.72 \mathrm{GJ} \mathrm{ha}^{-1}$ input energy while EROI was 1.13. NAMDARI et al. (2011) investigated 110 citrus orchards (orange and mandarin) in Mazandaran province of Iran. Mandarin production had more intensive energy than orange. Results showed that input energy consumed by orange orchards was $62.37 \mathrm{GJ}^{-1} \mathrm{a}^{-1}$ while mandarin was $77.50 \mathrm{GJ} \mathrm{ha}^{-1}$. Orange and mandarin EROIs were 0.99 and 0.77, respectively (Table 6). We must emphasize that both authors considered a single productive year while this study approached the whole productive cycle (18 years), in which there are years without production (from planting to $3^{\text {rd }}$ year) and with smaller production $\left(4^{\text {th }}\right.$ and from $15^{\text {th }}$ to $18^{\text {th }}$ years). There was no information about citrus or citrus life cycle in literature references and our data are important to evaluate crop establishment participation in energy demand.

TABLE 6. Comparison of energy indicators with literature references.

\begin{tabular}{lccccc}
\hline Indicator & Unit & This study & $\begin{array}{c}\text { OZKAN et al. } \\
(2004)\end{array}$ & $\begin{array}{c}\text { PIMENTEL } \\
(2009)\end{array}$ & $\begin{array}{c}\text { NAMDARI et al. } \\
(2011)\end{array}$ \\
\hline $\mathrm{CY} \mathrm{yr}^{-1}$ & $\mathrm{~kg} \mathrm{ha}^{-1} \mathrm{yr}^{-1}$ & 34032.64 & 40000.00 & 48000.00 & 32500.00 \\
$\mathrm{OE} \mathrm{yr}^{-1}$ & $\mathrm{GJ} \mathrm{ha}^{-1} \mathrm{yr}^{-1}$ & 64.66 & 76.00 & 94.97 & 61.75 \\
$\mathrm{IE} \mathrm{yr}$ & $\mathrm{GJ} \mathrm{ha}^{-1} \mathrm{yr}^{-1}$ & 38.07 & 60.95 & 83.72 & 62.37 \\
$\mathrm{~EB} \mathrm{yr}^{-1}$ & $\mathrm{GJ} \mathrm{ha}^{-1} \mathrm{yr}^{-1}$ & 26.59 & 15.05 & 11.25 & -0.62 \\
EROI & - & 1.70 & 1.25 & 1.13 & 0.99 \\
EE & $\mathrm{MJ} \mathrm{kg}^{-1}$ & 1.12 & 1.52 & 1.74 & 1.92 \\
\hline
\end{tabular}

CY - Citrus yield; OE - Output energy; IE - Input energy; EB - Energy balance; EROI - Energy return on investment; EE - Embodied energy.

After considering three efficiency scenarios (minimum, typical and maximum), it was checked the effect of field efficiency in energy demand for citrus production (Table 7). Regarding indirect energy demand for the three field efficiency levels, the value of total indirect applied 
energy was $7.6 \%$ higher for minimum one and $11.4 \%$ lower for maximum one, both in comparison with typical one. The increase in energy demand percentage came from machinery depreciation $(+9.4 \%)$ for minimium efficiency. On the other hand, labor reached the highest improvement percentage $(-11.8 \%)$ in its energy demand when maxium efficiency was applied. A proper machinery management may propitiate environmental benefits besides expected economical ones by saving natural resources and performing same acitvity.

TABLE 7. Energy demand for citrus production under field efficiency scenarios for mechanized operations.

\begin{tabular}{|c|c|c|c|c|c|}
\hline \multirow{3}{*}{ Input } & \multicolumn{5}{|c|}{ Efficiency } \\
\hline & \multirow{2}{*}{$\begin{array}{c}\text { Typical } \\
\text { IE }\left(G J h^{-1}\right)\end{array}$} & \multicolumn{2}{|c|}{ Minimum } & \multicolumn{2}{|c|}{ Maximum } \\
\hline & & IE $\left(\mathrm{GJ} \mathrm{ha}^{-1}\right)$ & $\Delta \%$ & IE $\left(G J h^{-1}\right)$ & $\Delta \%$ \\
\hline Fuel & 265.7 & 285.1 & 7.3 & 235.3 & -11.4 \\
\hline Mach. Depreciation & 38.3 & 41.9 & 9.4 & 34.0 & -11.2 \\
\hline Labor & 1.7 & 1.8 & 5.9 & 1.5 & -11.8 \\
\hline Total & 305.7 & 328.8 & 7.6 & 270.8 & -11.4 \\
\hline
\end{tabular}

The point in which invested energy is paid back through citrus production was compared within three scenarios for field efficiency. This happens when output energy surpasses the amount of input energy during the productive life cycle. All efficiency scenarios had invested energy paid back in seventh year. Even though, in this study, differences among field efficiencies were not so sharp, it shows to be an interesting tool in order to compare production systems with different input energies and similar output. If yields are not so favorable, discrepancy among scenarios will be higher. Energy output (based in yield) varied in $10 \%$ less and more, to check effects of yield increases on energy payoff investment that citrus field demands. All combinations between efficiency and yield levels became positive (output higher than input) in the seventh year, except for minimum efficiency and $10 \%$ less yield combination, which is positive in the eighth year. On the other hand, the best combination (maximum efficiency and $10 \%$ more yield) pays the investment in the edge of the sixth and seventh year.

Energy indicators were also determined for the three field efficiency scenarios (Table 8). EB showed the highest improvement with maximum efficiency. Minimum efficiency affected EB, EE and EROI similarly. There was a difference between maximum and typical of about $35 \mathrm{GJ} \mathrm{ha}^{-1}$ for EB that is more than demanded energy for limestone application or ammonium sulphate, for instance.

TABLE 8. Energy indicators for citrus production under three scenarios of field efficiency.

\begin{tabular}{|c|c|c|c|c|}
\hline \multirow{2}{*}{ Indicator } & \multirow{2}{*}{ Unit } & \multicolumn{3}{|c|}{ Efficiency level } \\
\hline & & Typical & $\operatorname{Minimum}(\Delta)$ & $\operatorname{Maximum}(\Delta)$ \\
\hline EROI & & 1.70 & $1.64(-3.53 \%)$ & 1.79 (5.29\%) \\
\hline EB & GJ ha ${ }^{-1}$ & 78.69 & $455.67(-4.81 \%)$ & $513.55(7.35 \%)$ \\
\hline EB $\mathrm{yr}^{-1}$ & GJ ha $\mathrm{yr}^{-1}$ & 26.59 & $25.31(-4.81 \%)$ & $28.53(7.35 \%)$ \\
\hline EE (citrus) & $\mathrm{MJ} \mathrm{kg}^{-1}$ & 1.12 & $1.16(3.57 \%)$ & $1.06(-5.36 \%)$ \\
\hline EE (vitamin C) & $\mathrm{MJ} \mathrm{kg}^{-1}$ & 3033.43 & $3135.34(3.36 \%)$ & $2880.46(-5,09 \%)$ \\
\hline
\end{tabular}

Sensitivity analysis referring to direct and indirect energy demands of energy indicators is showed in Figure 1, where initial amounts of each element (machinery depreciation, fuel, fertilizers and pesticides) was decreased in $10 \%$.

There was a variation of $-10 \%$ in material flow of each input for total value, fuel and machinery depreciation in Table 2; and for pesticides and fertilizers of the material flow in Table 3. 


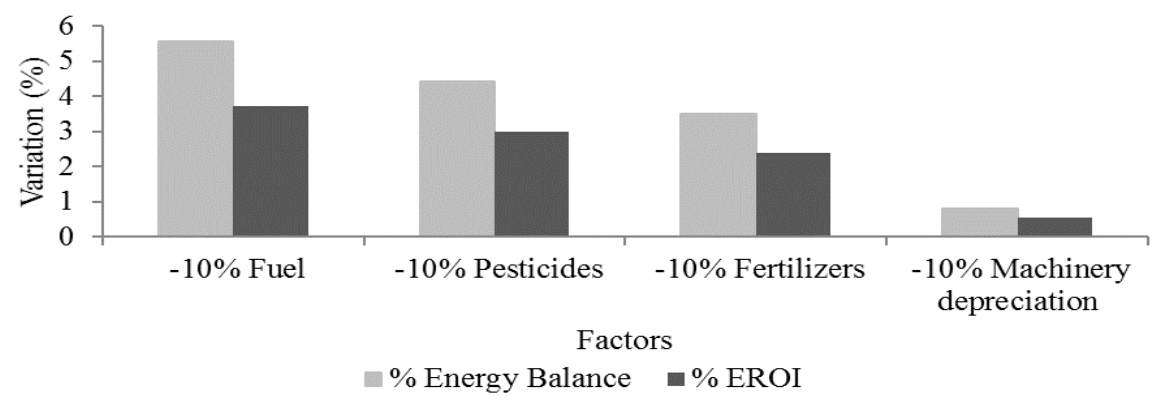

FIGURE 1. Sensitivity analysis of the energy indicators.

Fuel is the responsible factor for the largest rate in energy indicators (EB and EROI), since it corresponds to the largest share in direct energy demand of the production system (38.77\%), followed by "pesticides" (30.83\%) and "fertilizers" (24.50\%), which components for this evaluation were grouped into these categories, unlike fuel, which was analised individually. One way to reduce fuel consumption is to increase operational capacity of mechanized set, by field capacity improving, as analysis presented in table 8. For spraying, for example, which has the highest fuel demand among all operations, when considering a typical efficiency of 80\% (ASABE, 2011), demanded fuel energy is $129.04 \mathrm{MJ} \mathrm{ha}^{-1}$. However, for an efficiency of $90 \%(+12.5 \%)$, this demand decreases into 114.13MJ ha-1 (about -11.5\%).

\section{CONCLUSIONS}

We identified that fuel (38.77\%), pesticides (30.83\%), and fertilizers (24.50\%) are the main sources of energy demand. Labor and seedlings can be neglected for further studies with citrus and for perennial crops with similar production systems. Raising operational capacity of mechanized set by increasing field efficiency is a way to reduce fuel consumption. For spraying, which has the highest fuel demand among all operations, when considering a typical efficiency (80\%), demanded fuel energy is $129.04 \mathrm{MJ} \mathrm{ha}^{-1}$. However, for an efficiency of $90 \%$, energy demand reduces into $11.5 \%$.

Regarding distinct efficiencies of machinery field capacity, typical efficiency and the observed yield became positive in the seventh year. Minimum efficiency and $10 \%$ less yield was positive in the eighth year. The best scenario: maximum efficiency and $10 \%$ more yield was positive in the edge of the sixth and seventh production year, providing the following 12 years energy profitability. The worst scenario (minimum efficiency and $10 \%$ less yield) would reduce energy profitability to 10 years. Sensitivity analysis indicated that the bottlenecks of energy demand were fuel, pesticides and fertilizers, which, if reduced in $10 \%$, would improve energy balance and EROI respectively in $5.55 \%$ and $3.73 \%$ for fuel; $4.41 \%$ and $2.99 \%$ for pesticides; $3.51 \%$ and $2.39 \%$ for fertilizers.

\section{REFERENCES}

AGRIFNP. 2011: anuário da agricultura brasileira. São Paulo: FNP Consultoria \& Agroinformativos, 2011. 482p.

ASABE Standards. D497.7 Agricultural machinery management data. St. Joseph, EUA, 2011. 9p.

BOJACA, C.R.; SCHREVENS, E. Energy assessment of peri-urban horticulture and its uncertainty: case study for Bogota, Colombia. Energy, Amsterdam, v.35, n.5, p.2109-2118, 2010.

BOTEON, M.; PAGLIUCA, L.G. Análise da sustentabilidade econômica da citricultura paulista. Citrus Research, Cordeirópolis, v.31, n.2, p.101-106, 2010.

CARVALHO, L.M. Características físicas e químicas de laranjas Pêra Rio, Natal e Valência proveninentes de diferentes posições na copa. 2010. 65f. Dissertação (Mestrado) - Universidade de Viçosa, Viçosa, 2010. 
COUTO, M.A.L.; CANNIATTI-BRAZACA, S.G. Quantificação de vitamina C e capacidade antioxidante de variedades cítricas. Ciência e Tecnologia de Alimentos, Campinas, v.30, p.15-19, 2010.

FAO. 2011. FAOSTAT. Disponível em: http:<//www.faostat.fao.org>. Acesso em: 8 maio 2012.

FERRARO JR., L.A. Proposição de método de avaliação de sistemas de produção e de sustentabilidade.1999. 132f. Dissertação (Mestrado) - Escola Superior de Agricultura "Luiz de Queiroz”, Universidade de São Paulo, Piracicaba, 1999.

GRAFTON-CARDWELL, E.E.; STELINSKI, L.L.; STANSLY, P.A. Biology and management of Asian Citrus Psyllid, vector of the huanglongbing pathogens citrus research. Annual Review of Entomology, Stanford, v. 58, p.413-432, 2013.

JACOVINE, L.A.G.; VIANA, W.D.; ALVES, R.R.; WALTER, M.K.C.; SILVA, M.L.; VALVERDE, S.R. Environmental approach of companies within the pulp/paper, metallurgical and sugar/alcohol sectors. Scientia Agrícola, Piracicaba, v.66, n.1, p.1-7, 2009.

JASPER, S.P.; BIAGGIONI, M.A.M.; SILVA, P.R.A.; SEKI, A.S.; BUENO, O.C. Análise energética da cultura do crambe (Crambe Abyssinica Hochst) produzida em plantio direto. Engenharia Agrícola, Jaboticabal, v.30, n.3, p. 395-403, 2010.

MANTOAM, E.J.; MILAN, M.; GIMENEZ, L.M.; ROMANELLI, T.L. Embodied energy of sugarcane harvesters. Biosystems Engineering, London, v.118, p. 156-166, 2014.

MOLIN, J.P.; MILAN, M. Trator-implemento: dimensionamento. Capacidade operacional e custo. In: GONÇALVES, J.L.M.; STAPE, J.L. (Ed.). Conservação e cultivo de solos para plantações florestais. Piracicaba: Instituto de Pesquisas Florestais, 2002. p. 409-436.

MURPHY, D.J.; HALL, C.A.S. Year in review - EROI or energy return on (energy) invested. Annals of the New York Academy of Sciences, Issue Ecological Economics Review, New York, n.1185, p.102-118, 2010.

NAMDARI, M.; KANGARSHAHI, A.A.; AMRI, N.A. Input-output energy analysis of citrus production in Mazandaran province of IranYear. African Journal of Agricultural Research, Nairobi, v.6, n.11, p.2558-2564, 2011.

OLIVEIRA JR., E.D.; SEIXAS, F. Análise energética de dois sistemas mecanizados na colheita de eucalipto. Scientia Florestalis, São Paulo, n.70, p.49-57, 2006.

OZKAN, B.; AKCAOZ, H.; KARADENIZ, F. Energy requirement and economic analysis of citrus production in Turkey. Energy Conversion and Management, Oxford, v.45, n.11-12, p.1821-1830, 2004.

PIMENTEL, D. Handbook of energy utilization in agriculture. Boca Raton: CRC Press, 1980. 475 p.

PIMENTEL, D. Energy inputs in food crop production in developing and developed nations. Energies, Paris, v.2, n.1, p.1-24, 2009.

ROMANELLI, T.L.; MILAN, M. Energy performance of a production system of eucalyptus. Revista Brasileira de Engenharia Agrícola e Ambiental, Campina Grande, v.14, p.896-903, 2010a.

ROMANELLI, T.L.; MILAN, M. Material flow determination through agricultural machinery management. Scientia Agricola, Piracicaba, v.67, n.4, p.375-383, $2010 \mathrm{~b}$.

ROMANELLI, T.L.; NARDI, H.S.; SAAD, F.A. Material embodiment and energy flows as efficiency indicators of soybean (Glycine max) production in Brazil. Engenharia Agrícola, Jaboticabal, v.32, n.2, p.261-270, 2012.

ULBANERE, R.C.; FERREIRA, W.A. Análise do balanço energético para a produção de milho no Estado de São Paulo. Engenharia Agrícola, Jaboticabal, v.4, p.35-42, 1989. 